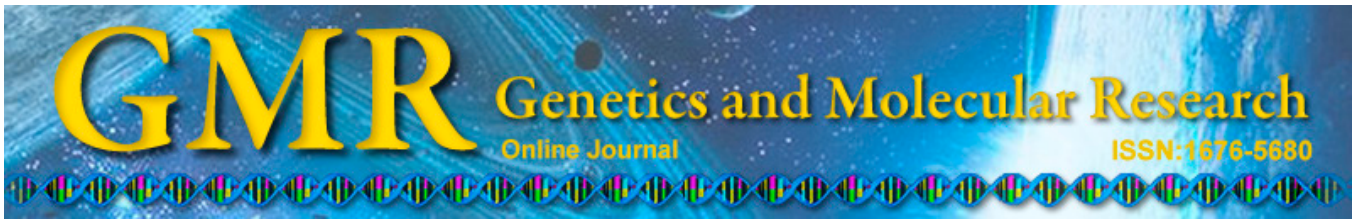

\title{
Application of molecular markers to detect DNA damage caused by environmental pollutants in lichen species
}

\author{
D. Cansaran-Duman', E. Altunkaynak², A. Aslan ${ }^{3}$, İ. Büyük² and S. Aras² \\ ${ }^{1}$ Ankara University, Biotechnology Institute, Tandogan, Ankara, Turkey \\ ${ }^{2}$ Department of Biology, Biotechnology Section, Science Faculty, \\ Ankara University, Tandogan, Ankara, Turkey \\ ${ }^{3}$ Department of Biology, Kazım Karabekir Education Faculty, \\ Ataturk University, Erzurum, Turkey \\ Corresponding author: D. Cansaran-Duman \\ E-mail: dcansaran@yahoo.com
}

Genet. Mol. Res. 14 (2): 4637-4650 (2015)

Received July 23, 2014

Accepted December 10, 2014

Published May 4, 2015

DOI http://dx.doi.org/10.4238/2015.May.4.23

ABSTRACT. Pseudevernia furfuracea L. (Zopf), Peltigera praetextata (Flörke ex Sommerf.) Zopf, Lobaria pulmonaria (L.) Hoffm., and Usnea longissima Ach. lichen species were used as bioindicators to assess the genotoxicity of air pollutants. In the present study, we examined significant environmetal pollutants and investigate how changes may lead to damage in DNA structure using RAPD markers. In the study area (Erzurum, Turkey), poor-quality lignite, which generates a large amount of sulfur dioxide, nitrogen oxides, and particle matter, is used for domestic heating, and vehicles also contribute to air pollution. Control lichen samples were collected far from large urban and industrial settlements and transplanted to four polluted sites for 4,8 , or 12 months. The total soluble protein content of the examined four lichen species did not significantly change with exposure time (P $<0.05)$. The four lichen samples exposed to the pollutants for 8 months had the highest ratio of DNA changes. The ratio of band differences 
in P. praetextata was higher than that in the other three lichen species, possibly because it has broad leaves that accumulated more pollutants. The average incidences of polymorphism were 64.14, 54.58, 65.76, and $43.06 \%$ for $P$. furfuracea, P. praetextata, L. pulmonaria, and $U$. longissima, respectively. The genomic template stability (GTS) significantly decreased following exposure to pollutants. GTS ratios revealed that the highest value $(98.36 \%)$ belonged to $U$. longissima samples from Site $1(10 \mathrm{~m})$ after 4 months of exposure, and the lowest values belonged to $P$. praetextata $(73.58 \%)$ from Site $3(100 \mathrm{~m})$ after 8 months of exposure. Based on our findings, we recommend the use of P. praetextata as an indicator of genotoxicity.

Key words: Pollution; Random amplified polymorphic DNA; Lichen; Genotoxicity

\section{INTRODUCTION}

Air pollution is a serious environmental problem in modern cities. Metals are classified as amongst the most dangerous groups of anthropogenic environmental pollutants, due to their toxicity and persistence in the environment. Consequently, the evaluation of levels of metal deposition is of vital importance for the assessment of human exposure. Pollutants that are emitted from automobiles are very diverse. Fossil fuels contain many kinds of heavy metals that are emitted into the environment during combustion (Pecheyran et al., 2000). It is well known that automobiles are not only responsible for heavy metal pollution $(\mathrm{Cu}, \mathrm{Zn}$, and $\mathrm{Pb})$, but also for many other pollutants (e.g., hydrocarbons, nitrogen oxides, carbon monoxide, and carbon dioxide) (Çiçek and Koparal, 2003).

Vehicles (cars, buses, trucks, etc.) and industrial sources (factories, refineries, power plants, etc.) cause air pollution in urban areas, and many techniques have been developed to determine the levels and sources of this pollution. One of these methods is using organisms to identify and monitor air pollution (Conti and Cecchetti, 2001). Many different organisms have long been recognized as sensitive indicators of environmental conditions. Lichen species show differing degrees of sensitivity to air pollution, but are generally adversely affected by sulfur dioxide, heavy metals, fluorides, nitrogen oxides, and peroxyacetyl nitrate (Canas et al., 1997).

Several studies on lichens in relation to air pollution and metal deposition in different regions of the world have been conducted (Canas et al., 1997; Najera et al., 2002). Many studies have used the technique of lichen transplantation to monitor air pollution, and shortterm transplantations may be an easy and economical method to monitor airborne pollutants (Canas et al., 1997). In Turkey, a large number of pollution-monitoring studies that have used biological and chemical methods have shown the ability of lichens to absorb elements directly from the air and accumulate them in their tissues (Cansaran-Duman et al., 2009, Guidotti et al., 2009; Cansaran-Duman, 2011; Aslan et al., 2004, 2010, 2011).

Heavy metals, including essential ones, are genotoxic after exposure to certain dosages for long periods, and can cause damage such as additions, deletions, and point mutations in nucleic acids. Some of this damage may be repaired by mutation-repair mechanisms, but some could remain. In recent studies, it has been shown that changes in DNA due to genotoxic agents can be analyzed with DNA fingerprinting methods, such as random amplified polymorphic 
DNA (RAPD) and amplified fragment length polymorphism (Labra et al., 2003; Liu et al., 2005; Cenkçi et al., 2009; Aksoy-Körpe and Aras, 2011). Lichens have been used in the bioindication of metal accumulation for a long time, and physiological and chemical parameters have been used to evaluate environmental damage to lichens (Liu et al., 2005). However, several studies have also been published that have investigated the protective capacity of lichens against genotoxic agents, and lichens' putative genotoxicity indicator potential (Geyikoğlu et al., 2007; Agar et al., 2010; Cansaran-Duman et al., 2011, 2012, 2014; Aras et al., 2012; Güner et al., 2012).

Biological methods allow the direct assessment of the genotoxic potential of air contaminants, and lichens are considered sensitive and effective indicators of genotoxicity. The objective of the present study was to evaluate the genotoxic potential of four lichen species: Pseudevernia furfuracea L. (Zopf), Peltigera praetextata (Flörke ex Sommerf.) Zopf, Lobaria pulmonaria (L.) Hoffm., and Usnea longissima Ach. Our aim was to detect changes in RAPD profiles in control lichen species, in order to reveal the patterns of genetic variation influenced by traffic-originated metal pollution.

\section{MATERIAL AND METHODS}

\section{Study area}

Erzurum is located between $41^{\circ} 16^{\prime \prime} \mathrm{E}$ longitude and $39^{\circ} 55^{\prime \prime} \mathrm{N}$ latitude at an altitude of approximately $1950 \mathrm{~m}$ above sea level. It is on the southeastern part of a high plateau, and is one of the largest cities in Anatolia. The area is surrounded by the Dumlu Mountains to the north and the Palandöken Mountains to the south. Spring is wet, summer is hot and arid, and winter is cold and snowy. The annual mean temperature is $6^{\circ} \mathrm{C}$, the lowest monthly mean is $-8.3^{\circ} \mathrm{C}$, and the highest monthly mean is $20.2^{\circ} \mathrm{C}$. The mean temperature is below $8^{\circ} \mathrm{C}$ for approximately 220 days of the year.

\section{Lichen material}

P. furfuracea, P. praetextata, L. pulmonaria, and U. longissima samples were collected with part of their substrate in unpolluted areas located far from large urban or industrial settlements (Table 1). Each of the four lichen species were studied with three lichen control samples collected from different substrates within the same area (max. $10 \mathrm{~m}$ away from each other). The specimens were identified by studying their morphology, anatomy, and chemistry (Purvis et al., 1992; Wirth, 1995). The lichen was attached to non-metal cages $\left(50 \mathrm{~cm}^{2}\right)$ to avoid metal contamination. The cages were mounted at a height of $10 \mathrm{~cm}$ on wooden stands that were $5 \mathrm{~m}$ away from a road. Four lichen species were transplanted onto trees that were 10 , 50,100 , or $200 \mathrm{~m}$ from a main road and they were exposed to pollution for 4,8 , or 12 months after transplantation (Table 2).

\section{Total soluble protein level}

Lichen thalli were homogenized $(1: 1, \mathrm{w} / \mathrm{v})$ with $0.2 \mathrm{M}$ phosphate buffer, $\mathrm{pH} 7.0$, using a cold mortar and pestle. The homogenate was centrifuged at 27,000 $\mathrm{g}$ for $20 \mathrm{~min}$. The supernatant was used for assays of the total soluble protein content, which was determined according to Bradford (1976), with bovine serum albumin included as a standard. 
Table 1. Properties of non-polluted sites, lichen species, and substrates.

\begin{tabular}{|c|c|c|c|c|c|}
\hline Lichen species & Non-polluted areas & Altitude & Latitude & Longitude & Substrate \\
\hline Peltigera praetextata & Bulancak/Giresun & $1700 \mathrm{~m}$ & $40^{\circ} 38^{\prime \prime} 30^{\prime \prime}$ & $38^{\circ} 14^{\prime \prime} 30^{\prime \prime}$ & Mosses \\
\hline Pseudevernia furfuracea & Dereli/Giresun & $1550 \mathrm{~m}$ & $40^{\circ} 44^{\prime \prime} 30^{\prime \prime}$ & $38^{\circ} 20^{\prime \prime} 15^{\prime \prime}$ & Pinus sylvestris \\
\hline Lobaria pulmonaria & Dereli/Giresun & $1550 \mathrm{~m}$ & $40^{\circ} 44^{\prime \prime} 30^{\prime \prime}$ & $38^{\circ} 20^{\prime \prime} 15^{\prime \prime}$ & Fagus orientalis \\
\hline Usnea longissima & Dereli/Giresun & $1550 \mathrm{~m}$ & $40^{\circ} 44^{\prime \prime} 30^{\prime \prime}$ & $38^{\circ} 20^{\prime \prime} 15^{\prime \prime}$ & Picea orientalis \\
\hline
\end{tabular}

Table 2. Properties of urban sites and vehicle quantities.

\begin{tabular}{llr}
\hline Locality No. & Properties & Vehicles \\
\hline 1 & Erzurum-Istanbul highway $(10 \mathrm{~m})$ & 7,056 vehicles/day \\
2 & Gate of Atatürk University on Istanbul highway $(50 \mathrm{~m})$ & 8,640 vehicles/day \\
3 & Centre of city, Havuzbasi Place, cross roads junction $(100 \mathrm{~m})$ & 19,872 vehicles/day \\
4 & Main gate of Atatürk University $(200 \mathrm{~m})$ & 12,288 vehicles/day \\
\hline
\end{tabular}

\section{Genomic DNA isolation and RAPD procedure}

The sample collected from Dereli-Giresun, which should not have been exposed to any kind of contamination, was used as a control in RAPD experiments. DNA extraction was performed according to the protocol defined by Aras and Cansaran (2006). The concentration and purity of the DNA extracted was measured at OD 260 and at 260/280 nm absorbance ratios using a NanoDrop ${ }^{\mathrm{TM}}$ ND-1000 Spectrophotometer (Thermo Scientific, Wilmington, DE, USA).

Primer screening for RAPD analysis was performed using 13 primers (Table 3), and five of the 13 primers amplified clear and reproducible bands. A polymerase chain reaction (PCR) was performed in a reaction volume of $25 \mu \mathrm{L}$ that contained $200 \mathrm{ng}$ genomic DNA, $2.5 \mu \mathrm{L} 10 \mathrm{X}$ reaction buffer, $2.5 \mathrm{mM} \mathrm{MgCl}, 20 \mu \mathrm{M}$ dNTPs, $0.2 \mu \mathrm{M}$ primer, and $0.5 \mathrm{U}$ Taq polymerase (Promega, Madison, WI, USA), and $\mathrm{ddH}_{2} \mathrm{O}$ was added to the standard volume. The PCR was performed in a Biometra Thermal Cycler (Labrepco, Horsham, PA, USA). The PCR program consisted of the following steps: initial denaturation at $94^{\circ} \mathrm{C}$ for $30 \mathrm{~s}$, annealing at $36^{\circ} \mathrm{C}$ for $1 \mathrm{~min}$ for 35 cycles, extension at $72^{\circ} \mathrm{C}$ for $45 \mathrm{~s}$, and a final extension at $72^{\circ} \mathrm{C}$ for $8 \mathrm{~min}$. The amplified samples were loaded on $1.2 \%$ agarose gels (a mixture of $50 \%$ agarose and $50 \% \mathrm{Nu}$ Sieve GTG agarose; FMC Corporation, Wokingham, UK), and run at $100 \mathrm{~V}$ for $4 \mathrm{~h}$. For the detection of other DNA contaminants, a negative control PCR mix, without any template DNA, was also used. To test the reproducibility of the RAPD-PCR, the experiments were repeated at least twice for each primer, faint bands were ignored, and only reproducible bands obtained from repeated experiments were considered.

\section{Statistical analyses}

The criteria for the analysis of the RAPD profiles were the bands that appeared in the control samples (Table 4). Polymorphisms observed in RAPD profiles include the disappearance of a control band and the appearance of a new band (Atienzar et al., 1999; Liu et al., 2005) (Table 5). The genomic template stability (GTS\%) was calculated as:

$$
G T S=\left(1-\frac{a}{n}\right) \times 100 \%
$$


where $a$ represents the RAPD polymorphic profiles (the total number of polymorphic bands obtained for the five primers) in each sample exposed to environmental pollution around the city of Erzurum, and $n$ represents the total number of bands in the control. Changes in the RAPD patterns were expressed as decreases in the GTS, which was related to the change in the number of RAPD profiles generated by the lichen samples in the polluted areas in relation to profiles obtained from the control lichen samples (Table 6).

\begin{tabular}{ll}
\multicolumn{2}{c}{ Table 3. Sequence of the primers used in this study. } \\
\hline Names of primer & \\
\hline B389 & Sequence of primers $\left(5^{\prime} \rightarrow 3^{\prime}\right)$ \\
OPC01 & CGCCCGCAGT \\
OPC02 & TTCGAGCCAG \\
OPC03 & GTGAGGCGTC \\
OPC04 & GGGGTCTTT \\
OPC10 & CCGCATCTAC \\
OPO03 & TGTCTGGGG \\
OPO07 & CTGTTGCTAC \\
P437 & CAGCACTGAC \\
TubeA01 & GGTGCACGTT \\
TubeA02 & CGGATCGACA \\
TubeA03 & CAGGCCTTC \\
TubeA03 & TGCCGAGCTG \\
\hline
\end{tabular}

\section{RESULTS}

\section{Effect of pollution on total soluble protein levels}

The total soluble protein levels are presented in Figure 1. The total soluble protein content profiles of the control samples were similar to those of the four experimental lichen species. The total soluble protein content did not change significantly with exposure time to pollution $(\mathrm{P}<0.05)$.

\section{RAPD-PCR profiling of the control and experimental samples}

Thirteen different primers were used for the RAPD analysis (Table 3), and five of the primers yielded clear and reproducible bands. We evaluated five primers in the experimental samples and compared them with the control samples (Table 4). The profile obtained by the OPC02 primer is shown in Figure 2. The DNA concentrations of the samples were in the range 458 to $3624 \mathrm{ng} / \mu \mathrm{L}$, and the $260 / 280 \mathrm{~nm}$ ratios ranged from 1.61 to 1.78 . Some of the primers exhibited significant differences between the control and experimental samples in various parts of Erzurum (Table 4).

In this study, the control sites were located far from the experimental sites. Three different control samples for each species, which were collected randomly from different substrates, were used. Of the four sites, Site 3 was the closest to sources of pollution, as it was located near a road in Erzurum. Site 4 was close to Atatürk University. The highest band variations were found in these sites. Sites 1 and 2 were also close to a road (Table 2). Pollutants are probably emitted into the atmosphere from these sites by wearing of engine accent of vehicles in traffic. 
D. Cansaran-Duman et al.

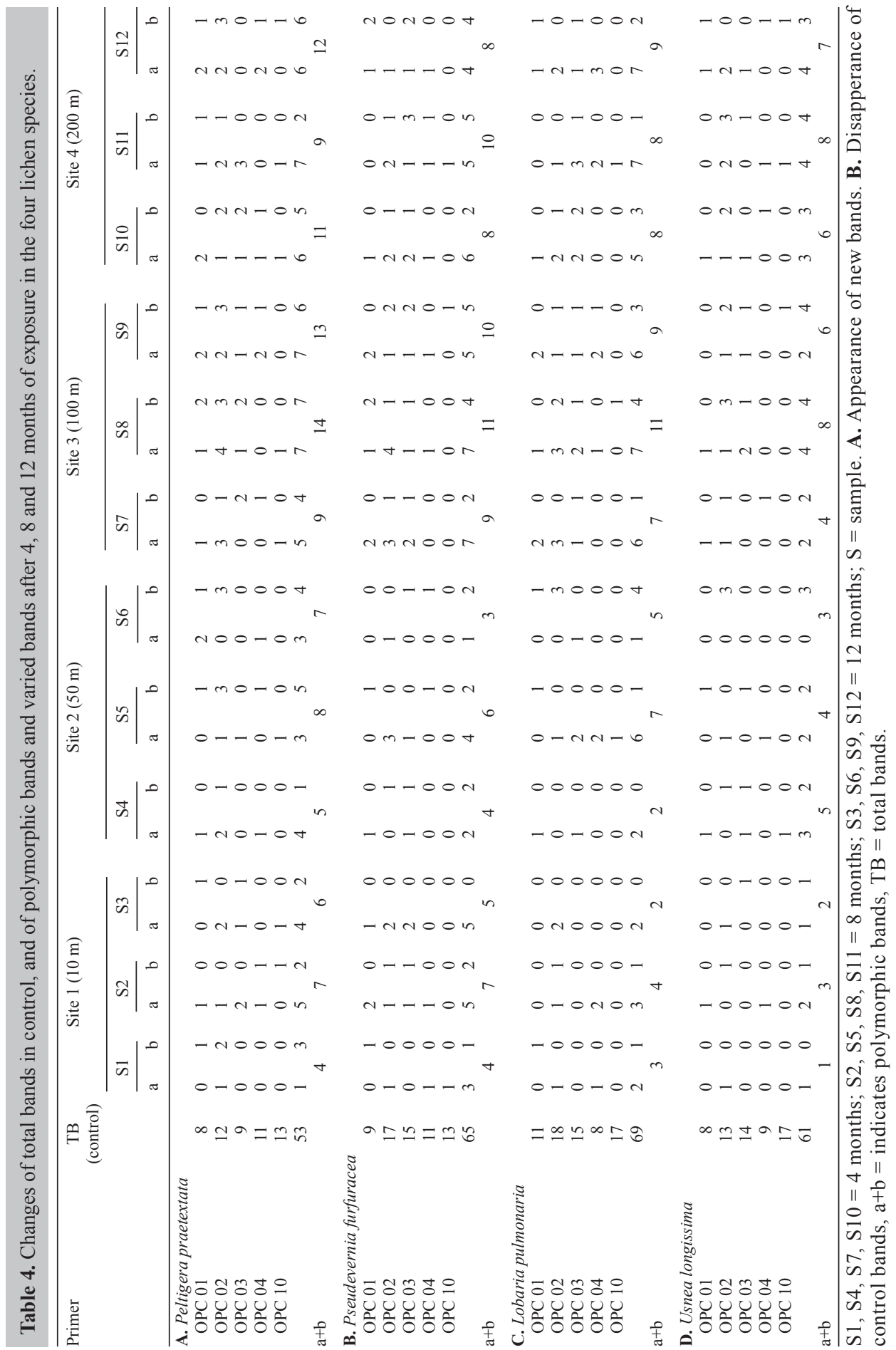




\begin{tabular}{|c|c|c|c|}
\hline Primers & TB & PB & Ratio (\%) \\
\hline \multicolumn{4}{|c|}{ Peltigera praextata } \\
\hline OPC 01 & 8 & 5 & 62.5 \\
\hline $\mathrm{OPC} 02$ & 12 & 10 & 83.3 \\
\hline OPC03 & 9 & 6 & 66.6 \\
\hline OPC04 & 11 & 6 & 54.5 \\
\hline OPC10 & 13 & 7 & 53.8 \\
\hline Total & 53 & 34 & 64.14 \\
\hline \multicolumn{4}{|c|}{ Pseudevernia furfuraceae } \\
\hline OPC01 & 9 & 6 & 66.6 \\
\hline $\mathrm{OPC} 02$ & 17 & 12 & 70.6 \\
\hline OPC03 & 15 & 8 & 53.3 \\
\hline OPC04 & 11 & 4 & 36.3 \\
\hline OPC10 & 13 & 6 & 46.1 \\
\hline Total & 65 & 36 & 54.58 \\
\hline \multicolumn{4}{|c|}{ Lobaria pulmonaria } \\
\hline OPC01 & 11 & 7 & 63.7 \\
\hline $\mathrm{OPC} 02$ & 18 & 14 & 77.8 \\
\hline OPC03 & 15 & 10 & 66.7 \\
\hline OPC04 & 8 & 4 & 50.0 \\
\hline OPC10 & 17 & 12 & 70.6 \\
\hline Total & 13.8 & 9.4 & 65.76 \\
\hline \multicolumn{4}{|c|}{ Usnea longissima } \\
\hline OPC01 & 8 & 2 & 25.0 \\
\hline OPC02 & 13 & 5 & 38.4 \\
\hline OPC03 & 14 & 6 & 42.8 \\
\hline OPC04 & 9 & 4 & 44.4 \\
\hline OPC10 & 17 & 11 & 64.7 \\
\hline Total & 12.2 & 5.6 & 43.06 \\
\hline
\end{tabular}

$\mathrm{TB}=$ total bands; $\mathrm{PB}=$ polymorphic bands.

Table 6. Changes of genomic template stability (GTS) for all primers in this study.

\begin{tabular}{|c|c|c|c|c|c|}
\hline \multirow[t]{2}{*}{ Sites } & \multirow[t]{2}{*}{ Samples } & \multicolumn{4}{|c|}{ GTS ratio $(\%)$} \\
\hline & & Peltigera praetextata & Pseudevernia furfuracea & Lobaria pulmonaria & Usnea longissima \\
\hline \multirow[t]{3}{*}{ Site $1(10 \mathrm{~m})$} & $\mathrm{S} 1$ & 92.45 & 93.84 & 95.65 & 98.36 \\
\hline & $\mathrm{S} 2$ & 86.79 & 89.23 & 94.20 & 95.08 \\
\hline & S3 & 88.67 & 92.30 & 97.10 & 96.72 \\
\hline \multirow[t]{3}{*}{ Site $2(50 \mathrm{~m})$} & S4 & 90.56 & 93.84 & 97.10 & 91.80 \\
\hline & S5 & 84.90 & 90.76 & 89.85 & 93.44 \\
\hline & S6 & 86.79 & 95.38 & 92.75 & 95.08 \\
\hline \multirow[t]{3}{*}{ Site $3(100 \mathrm{~m})$} & S7 & 83.01 & 86.15 & 89.85 & 93.44 \\
\hline & S8 & 73.58 & 83.07 & 84.05 & 86.88 \\
\hline & S9 & 75.47 & 84.61 & 86.95 & 90.16 \\
\hline \multirow{3}{*}{ Site $4(200 \mathrm{~m})$} & S10 & 79.24 & 87.69 & 88.40 & 90.16 \\
\hline & $\mathrm{S} 11$ & 83.01 & 84.61 & 88.40 & 86.90 \\
\hline & S12 & 77.35 & 87.69 & 86.95 & 88.52 \\
\hline
\end{tabular}

S1, S4, S7, S10 = 4 months; S2, S5, S8, S11 = 8 months; S3, S6, S9, S12 = 12 months.

Changes in band numbers, in the form of band appearances and disappearances, were determined (Table 4 and Figure 2). The highest number of band appearances and disappearances was found at Site $3(100 \mathrm{~m})$ after 8 months of exposure. The molecular size of the disappearing bands ranged from 427 to $1632 \mathrm{bp}$. Sites 2 and 4 also exhibited a higher number of band appearances and disappearances than the control samples.

Pollutants are probably emitted into the atmosphere by the engines and tires of vehicles, and may be present in the fuel composition of exhausts. P. praetextata was the greatest accumulator of pollution. 


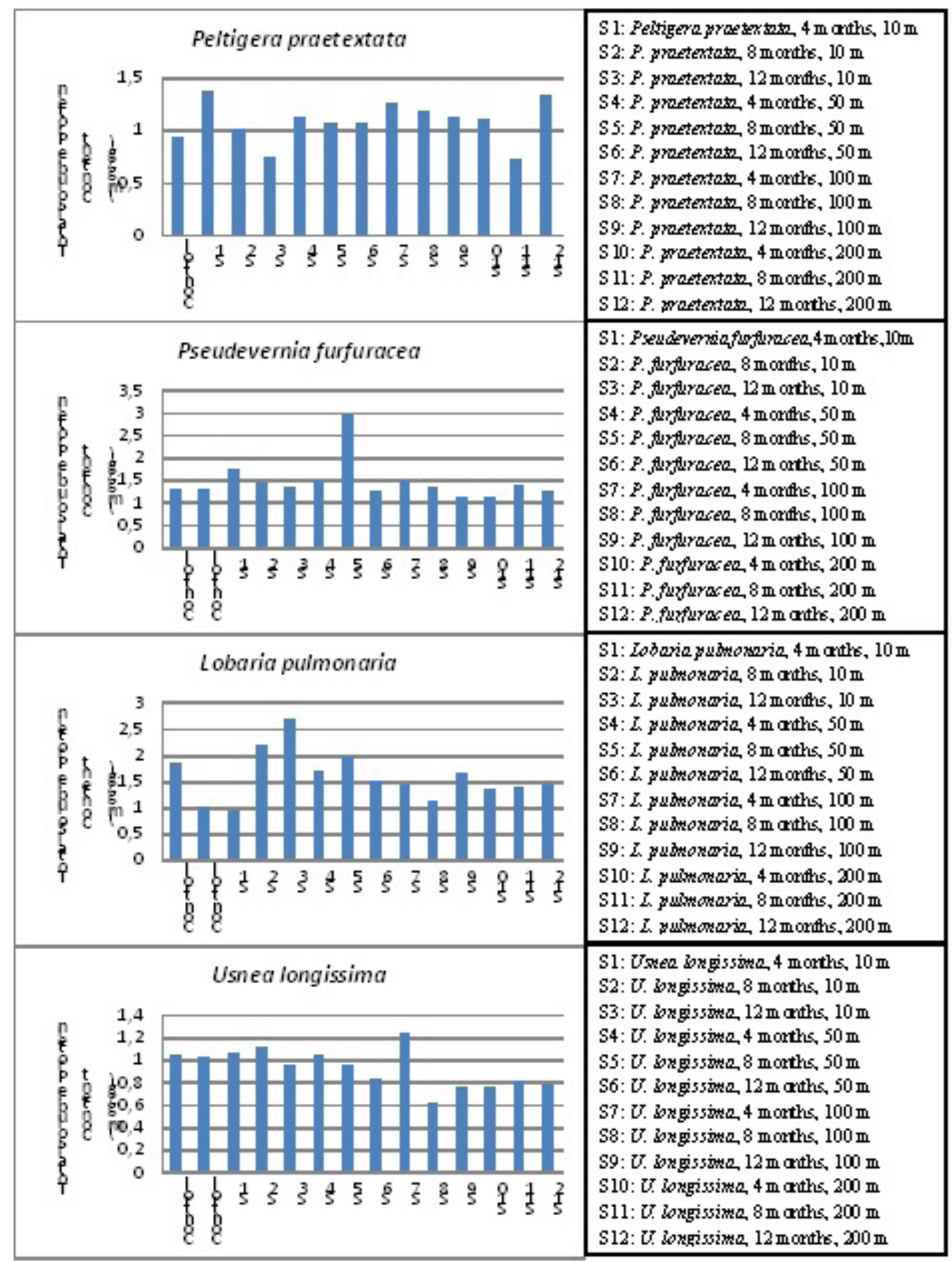

Figure 1. Total soluble protein content $(\mathrm{mg} / \mathrm{g})$ after 4, 8, and 12 months of exposure in the four lichen species. 
In a previous study, conducted in parallel with the same samples, some of the heavy metal concentrations were determined, and the lowest levels of heavy metals were found in $U$. longissima (Çiçek et al., 2008). The RAPD patterns generated in lichens from polluted sites were clearly different from those generated in the control group, and changed with increasing pollution. Site 1 was far from Erzurum's main road and had the lowest traffic density, which may have resulted in a low level of genotoxic effects, as the samples from this location exhibited the lowest GTS. The greatest genotoxic effects were found after 8 months of exposure at Site 3, which was the most polluted (19,872 vehicles/day; Table 2). Genotoxic effects on the four lichen species tended to decrease from high-density traffic areas to low-density (7056 vehicles/day) traffic areas. In addition, as Figure 2 shows, the optimal RAPD patterns obtained with all of the primers confirmed that the variation in the bands was stable.

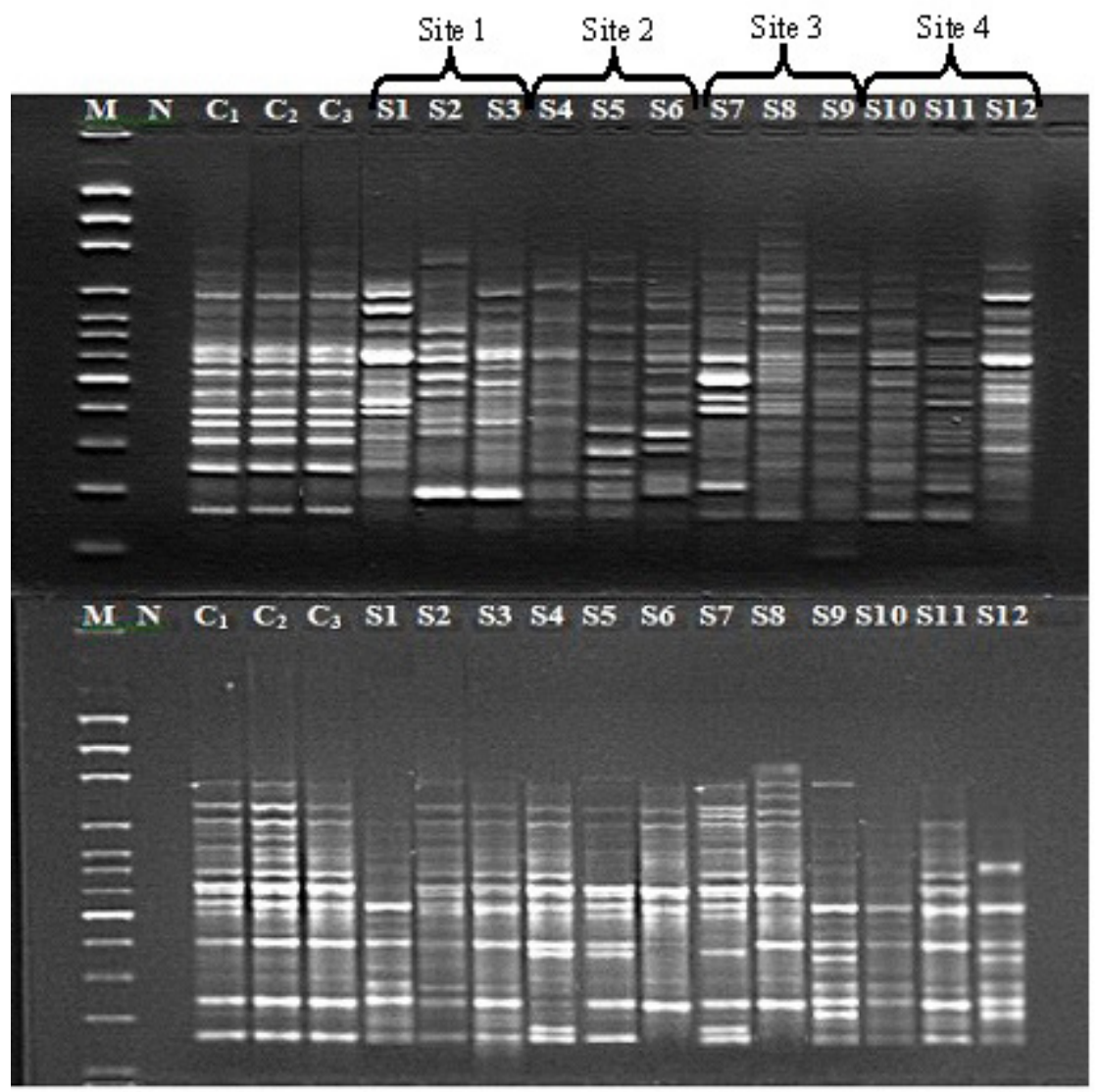

Figure 2. Random amplified polymorphic DNA profiles generated by the OPC02 primer from Peltigera praetextata and Usnea longissima samples exposed to polluted areas in Erzurum, Turkey. Lane $M=$ molecular weight marker (100-bp ladder).

The primer OPC02 yielded 12 clear, reproducible bands in the P. praetextata control, and after 8 months of exposure bands disappeared and reappeared in polluted samples from Site $3(100 \mathrm{~m})$ in Erzurum (Table 4). The same primer yielded more band appearances and dis- 
appearances in the other examined lichen species (P. furfuracea, L. pulmonaria, and U. longissima) after 8 months of exposure (Table 4). A total of 53 bands in P. praetextata were amplified by five primers in the control samples, which generated bands between 8 (OPC01) and 13 (OPC10), with an average of 11 bands per primer (Table 4). For P. furfuracea, L. pulmonaria, and $U$. longissima, 65, 69, and 61 bands, respectively, were amplified. The RAPD profiles exhibited substantial differences between the control and polluted samples. In addition, variation in the number of amplified DNA fragments depended upon the distance from the source of pollution. In total, 47, 31, 20, and 29 normal RAPD bands of the control samples disappeared in $P$. praetextata, . furfuracea, L. pulmonaria, and $U$. longissima, respectively. The highest number of disappearing bands for the primers OPC02 and OPC 03 were at Site 3 after 8 months of exposure (Table 4). OPC02 exhibited its maximum number of band disappearances and appearances (out of 14 bands) after 8 months of exposure in P. praetextata (Table 4).

The total band variations $(\mathrm{a}+\mathrm{b})$ are also displayed in Table 4 . The exposed sample in $P$. praetextata exhibited 105 band variations, and $P$. furfuracea exhibited 85, L. pulmonaria 76, and $U$. longissima 57 . The $P$. praetextata and $P$. furfuracea samples transplanted to polluted sites in Erzurum exhibited greater DNA variation than did L. pulmonaria or U. longissima (Table 4). The number of new band appearance at all of the sites was very low, in all of the lichen species. The number of disappeared bands was highest at Site 3 after 8 months of exposure, and lowest at Site $1(10 \mathrm{~m})$ after 4 months of exposure (Table 4$)$. The amount of band variation also seemed to depend on the distance from a pollution source. The greatest amount of band variation was observed at Site 3, where human activity and traffic density was high, after 8 months of exposure in P. praetextata. Our results are in accordance with the morphological features of lichens. P. praetextata has broad leaves and contained the highest metal concentrations, whereas $U$. longissima has narrow leaves and contained the lowest metal concentrations, indicating that surface area is an important factor in lichen metal trapping. The accumulation of heavy metals in lichens is strongly correlated with concentrations of airborne heavy metals (Ferry et al., 1973).

Samples that were from sites that were close to sources of pollution (e.g., Site 1) exhibited a higher number of polymorphisms in their RAPD profiles than did the control samples (Table 5). Of the primers used, OPC02 exhibited the highest number of polymorphisms. The ratio of polymorphisms was calculated as the number of polymorphic bands/total bands $\mathrm{x} 100$ (Table 5). According to this calculation, the appearance of a new band, or the disappearance of an existing band, in comparison with a control, is considered polymorphic. Changes in band intensity were ignored, as they rarely occurred.

The GTS is related to the level of DNA damage and the efficiency of DNA repair and replication. Therefore, a high level of DNA damage does not necessarily decrease the GTS (in comparison to a low level of DNA alteration), because DNA repair and replication are inhibited by a high frequency of DNA damage. The GTS results are presented in Table 6 . The highest GTS value was detected at Site $1(98.3 \%)$ in U. longissima, and the lowest was found at Site $3(73.5 \%)$ in P. praetextata (Table 6).

\section{DISCUSSION}

In the present study, we found significant differences between lichen specimens from four polluted sites and controls in RAPD patterns, which exhibited apparent changes (the disappearance of a normal band and/or the appearance of extra bands) in the number and size of 
amplified DNA fragments. The changes observed in the RAPD patterns were probably due to the DNA alterations caused by heavy metals and other kinds of pollutant. Table 4 summarizes the alterations detected in RAPD profiles. All three controls, in all of the experiments, exhibited the same banding pattern. The RAPD profiles generated by primer OPC02 are shown in Figure 2. The highest number of band changes (14) was detected at Site 3 after 8 months of exposure in P. praetextata.

Air pollution represents a threat both to the environment and to human health, and it is estimated that millions of tons of toxic pollutants are released into the air each year. Mines, metal foundries, cement factories, power plants, compost factories, waste treatment facilities, and busy roads are examples of emission sources of genotoxic agents, particularly heavy metals such as $\mathrm{Cr}, \mathrm{Ni}, \mathrm{Mn}$, and $\mathrm{Pb}$. Furthermore, using coal for heating in cities causes a considerable amount of heavy metal pollution. As a result, the detection of DNA polymorphisms using RAPD analysis could be used as an investigative tool in environmental toxicology, after rigorously optimizing its conditions of use.

The detection of genotoxic effects using RAPD involves the comparison of DNA amplification profiles generated from control (unexposed) and exposed samples. The changes in RAPD profiles must be interpreted carefully. Indeed, the frequency of band appearances and disappearances may allow a better understanding of the results. In the current study, DNA damage induced by various environmental pollutants, and other factors, was reflected by changes in RAPD profiles: the disappearance of normal RAPD bands and the appearance of new PCR products. It has been suggested that alterations to RAPD profiles due to genotoxic exposure can be regarded as alterations to the GTS (Atienzar et al., 1999). The results indicate that the GTS in $P$. praetextata was significantly affected by pollution near the main road in Erzurum (Table 6). According to Liu et al. (2005), modifications of band intensity and lost bands are probably due to one or a combination of the following events: 1) changes in oligonucleotide priming sites, mainly due to genomic rearrangements, and, to a lesser extent, point mutations; 2) DNA damage to the primer binding sites; and 3) interactions between DNA polymerase and damaged DNA in the test organism. However, the appearance of a new DNA band could occur, because some oligonucleotide priming sites could become accessible to oligonucleotide primers after structural change, or because changes in DNA sequences have occurred due to mutations, large deletions, and/or homologous recombination (Atienzar et al., 1999).

A differential rate of increase in metal concentrations has been found both in samples from transplant studies and in samples exposed to heavy metals for longer periods of time. In studies in which $\mathrm{Pb}$ pollution has been investigated, Ward (1989) and Al-Chalabi and Hawker (2000) found that $\mathrm{Pb}$ pollution gradually increases in areas close to roads. Laaksovirta et al. (1976), Kapu et al. (1991), Garty et al. (1997), and Scerbo et al. (2002), as well as many other researchers, have reported similar results in lichens. The samples located in bags close to roads and the samples collected from areas close to roads contained very high $\mathrm{Pb}$ concentrations. The genotoxic effects of pollutants have been investigated in several studies (Savva, 1998; Atienzar and Jha, 2006). It has been shown that $\mathrm{Hg}$ and $\mathrm{Cr}$ can induce such DNA damage in organisms as single- and double-strand breaks, modified bases, abasic sites, DNA-protein crosslinks, oxidized bases, 8-hydroxyguanine, and even bulky adducts (Zhou et al., 2011). Xu et al. (2008) reported that Zn can also induce DNA strand breaks. However, to our knowledge, little information is available on lichens' potential genotoxicity indicator capacity against pollutants. In our laboratory, studies on lichen genotoxicity have begun in recent years (Aras et al., 2010; Cansaran-Duman et al., 2011), and DNA alterations in exposed P. furfuracea sam- 
ples and Evernia prunastri samples have been investigated using RAPD analysis, in order to reveal the patterns of genetic variation caused by various environmental pollutants (CansaranDuman et al., 2011, 2012, 2014; Aras et al., 2012). The findings of the current study confirm the notion that environmental pollutants, particularly heavy metals, cause DNA damage in organisms, and demonstrate the potential of RAPD analyses to monitor levels of genotoxicity in lichens. According to a previous study (Cansaran-Duman et al., 2011), the highest numbers of band changes in E. prunastri were found at Site 8, which is close to an iron and steel factory, and Site 10, which is close to an iron and steel factory in Karabük. In the present study, $P$. praetextata exhibited great ergenotoxic effects than P. furfuracea, L. pulmonaria, or U. longissima. Heavy metals are a major component of air pollution, and many studies have shown that concentrations of absorbed heavy metal elements in lichen samples increase with increasing proximity to polluted areas such as busy roads and steel mills, and are also dependent on exposure time. In the current study, genotoxic effects in all of the examined lichen species were much higher at Site 3 (which had the highest traffic density) than at the other sites.

PCR-based fingerprinting methods provide an efficient tool for the investigation of mutational changes. RAPD analysis can help determine not only the mutational effects of heavy metals, but also the mutational effects of organic and inorganic genotoxic agents on different organisms (Labra et al., 2003). These methods are useful, particularly for pollution studies, as they can quickly compare polluted and non-polluted samples simultaneously (Liu et al., 2005). In this study, lichen samples close to pollution sources were compared in order to provide genotoxicity information of the variety of pollutants found in the air. A number of polymorphic bands were observed in the P. praetextata samples taken from areas close to roads (Site 3). The results of a previous study, conducted in parallel, which found high levels of heavy metal deposition in the same samples, confirm the elevated levels of environmental pollution in the area (Çiçek et al., 2008).

GTS is a qualitative measure that measures changes in RAPD profiles. The GTS may be related to the level of DNA damage and the efficiency of DNA repair and replication (Atienzar et al., 1999), and could explain the appearance and disappearance of bands.

The lowest GTS values for P. praetextata, P. furfuracea, L. pulmonaria, and U. longissima at Site 3 were $73.58,83.07,84.05$, and $86.88 \%$, respectively (Table 6). The lowest GTS values were obtained in the lichen samples from Site 3, which may indicate the sensitivity of lichens to genotoxic stressors. Previous studies have also indicated that mutations, chromosomal rearrangements, and other DNA lesions could be the reason for variations in RAPD band patterns. It has been demonstrated that changes in RAPD profiles induced by pollution could be regarded as modifications to the GTS. Therefore, as stated by Atienzar et al. (2000) "a high level of DNA damage does not necessarily decrease the genomic template stability because DNA repair and replication are inhibited by the high frequency of DNA damage". As a result, even a one-band change or a slight decrease in the GTS might be important in an RAPD assay.

Our results indicate that the GTS could also be directly compared with variations in other parameters. It has been reported that the GTS is more sensitive than the soluble protein content in the lichen thallus (Liu et al., 2005). In the current study, the effect of pollutants on the total soluble protein content in lichens was also investigated. Total soluble protein content is an important indicator of reversible and irreversible alterations in metabolism, and can also be used as a biomarker (Singh and Tewari, 2003). The results obtained of the total soluble protein levels in response to pollutants in the four lichen species investigated are presented in Figure 1. 
The aim of the current study was to investigate the genotoxic effects of a mixture of environmental pollutants on organisms under natural conditions. In this regard, the induction of DNA band changes with one kind of stressor found in air pollution could provide evidence of the genotoxic potential of air pollution. In a previous study, a controlled experiment with one type of heavy metal treatment was conducted in our laboratory in order to examine the effects of a genotoxic agent in a controlled environment (Aras et al., 2010).

The best way to determine environmental genotoxicity maybe the direct quantification of the genotoxic effects of pollutants on living organisms. The present study shows the suitability of lichen for the detection of genotoxicity, and also provides information on levels of potential genotoxic agents. In conclusion, the lichen species $P$. praetextata has great potential as an indicator of genotoxicity, and using RAPD markers is a cheap and reliable method for studying genotoxicity in lichen.

\section{REFERENCES}

Agar G, Gulluce M, Aslan A, Bozarı S, et al. (2010). Mutation preventive and antigenotoxic potential of methanol extracts of two natural lichen. J. Med. Plants Res. 4: 2132-2137.

Aksoy-Körpe D and Aras S (2011). Evaluation of copper-induced stress on eggplant (Solanum melongena L.) seedlings at the molecular and population levels by use of various biomarkers. Mut. Res. 719: 29-34.

Al-Chalabi AS and Hawker D (2000). Distribution of vehicular lead in roadside soils of major roads of Brisbane, Australia. Water Air Soil Poll. 118: 299-310.

Aras S and Cansaran D (2006). Isolation of DNA for sequence analysis from herbarium material of some lichen species. Turk. J. Bot. 30: 449-453.

Aras S, Kanlıtepe Ç, Cansaran-Duman D, Halıcı MG, et al. (2010). Assessment of air pollution genotoxicity by molecular markers in the exposed samples of Pseudevernia furfuracea (L.) Zopf in the Province of Kayseri (Central Anatolia). J. Environ. Monit. 12: 536-543.

Aras S, Beyaztaş T, Cansaran-Duman D and Gökçe E (2012). Evaluation of genotoxicity of Pseudevernia furfuracea (L.) Zopf by RAPD analysis. Genet. Mol. Res. 10: 3760-3770.

Aslan A, Budak G and Karabulut A (2004). The amounts Fe, Ba, Sr, K, Ca and Ti in some lichens growing in Erzurum province (Turkey). J. Quant. Spect. Rad. Trans. 88: 423-431.

Aslan A, Apaydın G, Yazıcı K, Cengiz E, et al. (2010). Analysis of trace element concentrations of some lichens of Turkey. Asian J. Chem. 22: 389-400.

Aslan A, Çiçek A, Yazıcı K, Karagöz Y, et al. (2011). The assessment of lichens as bioindicator of heavy metal pollution from motor vehicles activities. Afr. J. Agric. Res. 6: 1698-1706.

Atienzar FA and Jha AN (2006). The random amplified polymorphic DNA (RAPD) assay and related techniques applied to genotoxicity and carcinogenesis studies: A critical review. Mut. Res. 613: 76-102.

Atienzar FA, Conradi M, Evenden AJ, Jha AN, et al. (1999). Qualitative assessment of genotoxicity using random amplified polymorphic DNA: comparison of genomic template stability with key fitness parameters in Daphnia manga exposed to benzo[a]pyrene. Environ. Toxicol. Chem. 18: 2275-2282.

Atienzar FA, Cordi B, Donkin ME and Evenden AJ (2000). Comparison of ultraviolet-induced genotoxicity detected by random amplified polymorphic DNA with chlorophyll fluorescence and growth in a marine macroalgae, Palmaria palmata. Aquat. Toxicol. 50: 1-12.

Bradford MM (1976). A rapid and sensitive method for the quantitation of micro-gram quantities of protein utilizing the principle of protein-dye binding. Anal. Biochem. 72: 254-284.

Canas MS, Orellana L and Pignata ML (1997). Chemical response of the lichens Parmotrema austrosinense and $P$. conferendum transplanted to urban and non-polluted environments. Annal. Bot. Fenn. 34: 27-34.

Cansaran-Duman D (2011). Study on accumulation ability of two lichen species (Hypogymnia physodes (L.) Nyl and Usnea hirta (L.) Weber ex F.H. Wigg) at iron-steel factory site, Turkey. J. Environ. Biol. 32: 839-844.

Cansaran-Duman D, Atakol O, Atasoy İ, Kahya D, et al. (2009). Heavy metal accumulation in Pseudevernia furfuracea (L.) Zopf from the Karabük iron-steel factory in Karabük, Turkey. Zeit. Für Naturforsc. C. 64: 717-723.

Cansaran-Duman D, Beyaztaş T, Atakol O and Aras S (2011). Assessment of the air pollution genotoxicity by RAPD in Evernia prunastri L. Ach. province of iron steel factory in Karabük, Turkey. J. Environ. Sci. 23: 1171-1178. 
Cansaran-Duman D, Aras S, Atakol O and Atasoy I (2012). Accumulation of trace elements and the assessment of the genotoxicity in the lichen Pseudevernia furfuracea transplanted to a polluted site in Ankara. Ekoloji 21: 1-14.

Cansaran-Duman D, Altunkaynak E and Aras S (2014). Heavy metal accumulation and genotoxicity indicator capacity of the lichen species, Ramalina pollinaria collected from around the iron-steel factory in Karabük, Turkey. Turk. J. Bot. 38: 477-490.

Cenkçi S, Yıldız M, Cigerci İH, Konuk M, et al. (2009). Toxic chemicals-induced genotoxicity detected by random amplified polymorphic DNA (RAPD) in bean (Phaseolus vulgaris L.) seedlings. Chemosphere 76: 900-906.

Çiçek A and Koparal AS (2003). The assessment of air quality and identification of pollutant sources in the Eskişehir region Turkey using Xanthoria parietina (L.) Th. Fr. (1860). Fresen. Environ. Bull. 12: 24-48.

Çiçek A, Koparal AS, Aslan A and Yazıcı K (2008). Accumulation of heavy metals from motor vehicles in transplanted lichens in an urban area. Commun. Soil Sci. Plant Anal. 39: 168-176.

Conti ME and Cecchetti G (2001). Biological monitoring: lichens as bioindicators of air pollution assessment - a review. Environ. Pollut. 114: 471-92.

Ferry BW, Baddeley MS and Hawksworth DL (1973). Air pollution and lichens. Athlone Press, University of London, London.

Garty J, Kloog N, Wolfson R and Cohen Y (1997). The influence of air pollution on the concentration of mineral elements, on the spectral reflectance response and on the production of stress-ethylene in the lichen Ramalina duriaei. New Phytol. 137: 587-597.

Geyikoglu F, Turkez H and Aslan A (2007). The protective roles of some lichen species on colloidal bismuth subcitrate genotoxicity. Toxicol. Ind. Health. 23: 487-492.

Guidotti M, Stella D, Dominici C, Blasi G, et al. (2009). Monitoring of traffic-related pollution in a province of central Italy with transplanted lichen Pseudevernia furfuracea. Bull. Environ. Contam. Toxicol. 83: 852-858.

Güner A, Turkez H and Aslan A (2012). The in vitro effects of Dermatocarpon intestiniforme (a lichen) extracts against cadmium induced genetic and oxidative damage. Ekoloji 21: 38-46.

Kapu MM, Ipaye MM, Ega RA and Akanya HO (1991). Lichens as bioindicators of aerial fallout of heavy metals in Zaria, Nigeria. Bull. Environ. Contam. Toxicol. 47: 413-416.

Laaksovirta K, Olkkonen H and Alakuijala P (1976). Observations on the lead content of lichen and bark adjacent to a highway in Southern Finland. Environ. Pollut. 11: 247-255.

Labra M, Di Fabio T, Grassi F, Regondi SM, et al. (2003). AFLP analysis as biomarker of exposure to organic and inorganic genotoxic substances in plants. Chemosphere 52: 1183-1188.

Liu W, Li P, Qi XM, Zhou Q, et al. (2005). DNA changes in bar-ley (Hordeum vulgare) seedlings induced by cadmium pollution using RAPD analysis. Chemosphere 61: 158-167.

Najera JM, Gonzalez MI, Rossil MR and Mendez VH (2002). A new method to assess air pollution using lichens as bioindicators. Rev. Biol. Trop. 50: 321-325.

Pecheyran C, Lalere B and Donard OFX (2000). Volatile metal and metalloid species ( $\mathrm{Pb}, \mathrm{Hg}, \mathrm{Se}$ ) in a European urban atmosphere (Bordeaux, France). Environ. Sci. Technol. 34: 27-32.

Purvis OW, Coppins BJ, Hawksworth DL, James PW, et al. (1992). The lichen flora of Great Britain and Ireland. Natural History Museum Publications, London.

Savva D (1998). Use of DNA fingerprinting to detect genotoxic effects. Ecotoxicol. Environ. Saf. 41: 103-106.

Scerbo R, Ristori T, Possenti L, Lampugnani L, et al. (2002). Lichen (Xanthoria parietina) biomonitoring of trace element contamination and air quality assessment in Pisa Province (Tuscany, Italy). Sci. Total Environ. 286: 27-40.

Singh PK and Tewari RK (2003). Cadmium toxicity induced changes in plant water relations and oxidative metabolism of Brassica juncea L. plants. J. Environ. Biol. 24: 107-112.

Ward NI (1989). Multielement contamination of British motorway environments. In: Heavy metals in the environment (Vernet JP, ed.). Proceeding of the International Conference, Geneva, 279-282.

Wirth V (1995). Die Flechten Baden-Wurttemberg. Ulmer, Stuttgart.

Xu ZD, Shi RH, Wang W, Tao RS, et al. (2008). DNA damage by the cobalt(II) and zinc(II) complexes of tetraazamacrocyclic in Tetrahymena thermophila. Afr. J. Biotechnol. 7: 3061-3065.

Zhou L, Li J, Lin X and Al-Rasheid KAS (2011). Use of RAPD to detect DNA damage induced by nitrofurazone in marine ciliate, Euplotes vannus (Protozoa, Ciliophora). Aquat. Toxicol. 103: 225-232. 